\title{
Application of ICT in Nigerian Educational System for Achieving Sustainable Development
}

\author{
Zainab Sambo Gidadawa, Mansur Bello Dogondaji \\ Department of Geography, Shehu Shagari College of Education, \\ Sokoto, Nigeria
}

\begin{abstract}
Information communication Technology (ICT) is an indispensable part of the contemporary world. Infact, culture and society have to be adjusted to meet the challenge of knowledge age. The pervasiveness of ICT has brought about rapid technological, social, political and economic transformation, which has eventuated in a network society organized around ICT. In view of the above therefore, the paper tries to highlight on the application of ICT in Nigerian educational system for achieving sustainable development. Also, the paper discusses the concept of ICT, sustainable development as well as the computer itself and its major components. Finally, the paper concludes on the challenges of ICT in Nigeria and some possible recommendations were offered.
\end{abstract}

Keywords: ICT; Sustainable Development; Computer hardware and software

\section{INTRODUCTION}

It is a known fact that the world has reduced to a mere global village through inter connectedness that linked groups, communities and nations together thereby eliminating distance and communication barrier. The present generation is known to be information era propelled by recent development in information and communication technology which permeates all spheres of human endeavours. Human activities in this era are rapidly changing to electronic pattern. According to Mac-Ikemanjima (2005), ICT have now become tools with revolutionary impact of how we see the world and how we live. In the long history of education, there have been four intellectual revolutions (Ashby, 1975 in Liman, 2008). The first occurred when the responsibility for educating the child was in large measure passed to the professionalized institution. The second occurred with the invention of writing and the formation of the written word. The third, like its predecessor, occurred with the invention of printing and its potential in disseminating literature. The fourth is to do with adopting of audiovisual materials and programmed instruction in education. The computer, for now, epitomizes the fourth revolution in education. Mac-Ikemanjima (2005) further argues that, this phenomenon (of ICT revolution) has gave birth to the contemporary e-commerce, egovernment, e-medicine and e-education.

The information breakthrough that facilities such advancement is directly connected to the development in technology precipitated by increased learning and research activities. Omoyefe (2008), stated that, "information has brought in a new dimension in education generally from pre-primary to tertiary institution. He argues that information and 
communication technology (ICT) is changing the way we do things and its effects on education system are obvious for all to see.

\section{DEFINITION OF ICT}

Abolade and Olalere (2008), defined information technology (IT) as, "Computer, auxiliary equipment, software and firmware (hardware) and similar procedures services (including support services) to a related resource". It is also defined in the same document as, any equipment or interconnected system or subsystem of equipment that is used in the automatic acquisition, storage, manipulation, management, movement, control, display, switching, interchange, transmission or reception of data or information (FRN, 2001). Thus, they can be regarded as the technologies used for accessing, processing, gathering, manipulating and presenting or communicating information. These could include software, hardware and even connectivity (Anderson and Baskin, 2002).

Tutu (2007) on the other hand, described information and communication technology as a medium which comprises IT facilities together with electronic devices that moves information from one destination to another which include radio, television set, computer, satellite, internet, telephone lines and mobile set etc. However, according to Prince ((2008), information and communication technology (ICT) are advances in technology that provide a rich global resource and collaboration for dissemination of ICT literacy exchange of ideas, which are critical for advancing meaningful educational initiative, training a high-skilled labour force, and understanding issues related to economic development.

\section{THE RELEVANCE OF ICT TO EDUCATION SECTOR}

It is generally accepted that nations whose educational system embraces the use of ICT based instruction excelled in the field of technical and scientific innovation. As such, many countries have resort to ICT based education for sustainable development. Basically, the use of ICT in education is mainly for pedagogical purposes- research, management and evaluation and network activities. ICT facilities which include computers, printers, scanners, projectors, mobile phones, radios, television sets, satellites and internet among other things are used as teaching aids and facilities for data analysis in research (with the use of some software packages such as SPSS). They are also used in data processing such as result and summaries, management information system and networking, local area network to connect various units within the school environment or wide area networking that connects various units at wide distance such as states or nations, e-registration and result display and more importantly the internet connection.

In their various attempt to analyze the trend of ICT application in education in Nigeria, many scholars have alluded to the country's giant strive to embrace ICT based education for sustainable development. Mac-Ikemanjima (2005), asserts that there are presently at least nine ICT education initiatives at various stages of development being carried out by the education co-ordinating agencies of government and the ministry of education.

They include:

1. The Nigerian University Network (NUNET) project.

2. The polytechnics Network (Polynet) project

3. The school net project. 
4. The Nigeria Education, Academic and Research Network (NEARNET) project

5. The Teacher Network project (Teach Net)

6. National Open University

7. National Virtual (Digital) Library (Ministry of Education/NUC)

8. National Virtual Library (Ministry of Science and Technology/NITDA)

9. National Information Communication and education programme of the presidency.

According to Abolade and Olalere (2005), information and communication technologies are essential tools in any educational system. They have the potentials of being used to meet the learning needs of individual students, promote equality of educational opportunities; offer high quality learning materials, increase self-efficacy and independence of learning among students, and improve teacher's professional development. Furthermore, ICTs offer great potential revolutionalizing school administration (Kirschner and Selinger, 2003; Moseley and Higgins, 1999, Williams 2000).

The Milken exchange on educational technologies (1998) had noted in her synthesis of research findings that ICT under the right condition has the following potentials in education.

First, it has the potential to acceleration, enrich and depend basic skills in reading, writing, mathematics and the sciences.

Second, it motivates and engages students in learning as they are encouraged to be more independent and responsible for their own learning.

Third, it helps to relate academics to the practices of today's work as the influence of ICTs is pervasive in every field. Furthermore, it is relevant in increasing the economic viability of tomorrows workforce, as students are prepared to be fluent in thinking with and suing technology in ensuring efficiency and effectiveness to their work places, thereby increasing productivity; also, it strengthens teaching as it provides powerful tools to teachers' repertoires, thereby enabling them to meet individual learners' needs. Information and communication technologies allow for networking with other teachers; thus teachers are more connected with each other to exchange ideas, share resources and improve teaching practices. In addition, ICTs provide opportunity for connecting school with top world, as learning is expanded beyond the classroom, thus relevant real life contact can be established. Finally, students and teachers can access information and resources, and they can communicate with experts and peers and make useful contributions to knowledge through electronic publications.

\section{CONCEPT OF SUSTAINABLE DEVELOPMENT}

Sustainable development is a difficult concept to define. This is because it is continually evolving and people have different perception of what sustainable societies will look like and how they will function. However, the World Commission on Environment and Development (1987) defines sustainable development as, 'development that meets the needs of the present without compromising the ability of the future generation to meet their own needs. Based on this definition, it is generally thought that sustainable development has three components which include; environment, society and economy which are interwoven.

Jinghan (1997) further stressed that, sustainable development means that generation should keep going. It emphasizes the creation of sustainable improvements in the quality of all people through increase in real income per capita improvements in education, health and general quality of life as well as quality of natural environmental resources. Put differently, the word refers to balancing the fulfillment of human needs with the protection of the natural 
environment so that these needs can be met not only in the present but in the indefinite future. The linkage between environment and development was first introduced in 1980, when the international union for the conservation of nature published the world conservation strategy and used the term sustainable development (Felix, 2007).

Sustainable development is also conceived to be structural transformation of the sociopolitical, economic and environmental fabrics of the society that could persist for a long period and guarantee a high standard of living without compromising fate of the future generation. It is achievable in the present trend by only a society whose development policies remain proactive and adaptive to present technology development and modern method of educational delivery.

\section{COMPUTER AND ITS COMPONENTS}

The computer is an umbrella term for all machines that take commands (input), work on the input according to specific instructions, and give results (output). According to C- Tech (2010), computer is an electronic machine capable of accepting data as input, processes such data and produces an output as meaningful information. The "analytical engine" designed by Charles Babbage around 1840 is considered as the first mechanical computer for two basic reasons. First, it was designed to solve more than one problem and so the computer is fed with instructions for every task it is to perform. Second, it has five components, which were to form the basic concepts of modern-day computers. These components were:

1. A store to hold numbers etc (we now refer to this as "memory").

2. Tth "mill" (which was an arithmetic unit to perform arithmetic operations)

3. A control unit to coordinate the various activities in the correct sequence

4. An input device to transfer both numbers and instructions into the machine.

5. An output device to display the result of the computations.

Thus, the modern-day computer is necessarily made up of an input unit ( 4 above), an output unit ( 5 above) and a central processing unit (1,2 and 3 above). Together, these constitute the computer hardware and this is only one side of the coin. The computer software is the other side of the coin (Bhatnagar and Ramani 1991).

\section{THE COMPUTER HARDWARE}

The hardware is also a generic term that refers to the machine known as the computer or all the physical components of the computer. For better understanding, the hardware can be classified into three in Fig. 1 below. 


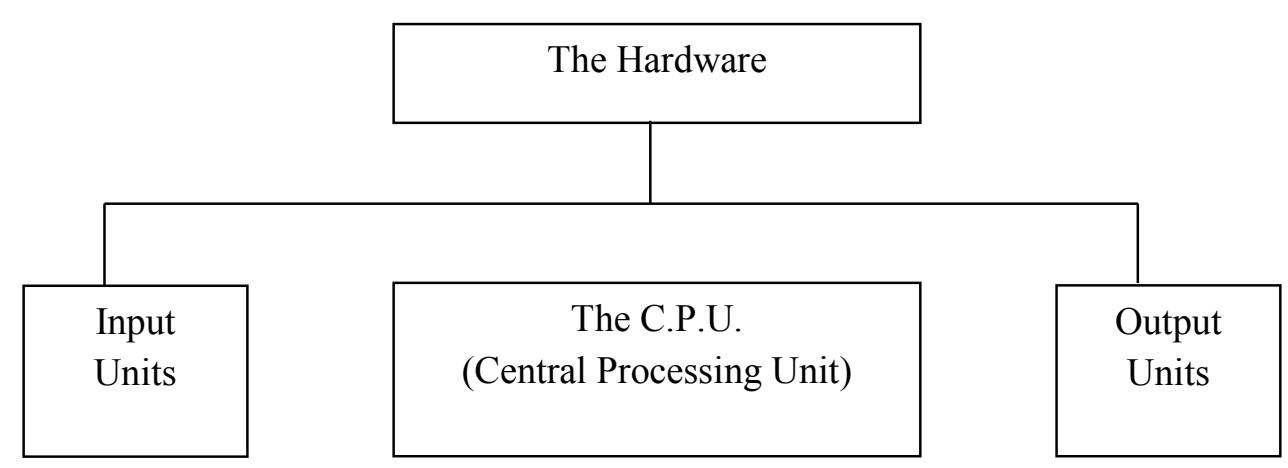

Fig. 1. The Computer Hardware.

The input units or devices refer to anything used to input data and /or instructions to the computer. They include the keyboard, the scanner, the digitizer, to some extent the mouse and any other device or gadget that is interfaced (attached) to the computer for the purpose of downloading data.

The CPU is a generic name for the component where a number of processes and actions take place inside the computer. The CPU is therefore said to control the computer as it decides what operation(s) to carry out and when to do so. It is therefore thought of as the "brain" of the computer. The nature and capacity of the CPU therefore distinguishes between the different computers, generally. The CPU must contain an arithmetic/logic unit (commonly referred to as the ALU, it is the "mill" which carries out arithmetic and logic operations) a memory unit (Registers), and internal communication lines.

The output units or devices provide the feedback interface between the computer and the user. The most important output devices include the monitor, printer and the plotter. The monitor is sometimes referred to as the screen or more technically the video display Unit (VDU) and gives a "screen copy" of whatever the user is involved with. The quality of outputs from monitors varies according to the adapters running them. The printer behaves more or less like a typewriter in that it reproduces any work done. Printers vary as to their capacities interms of speed indicated in characters per seconds (CPS), letter quality, buffer size, internal fonts and style features. In computer terms, the printer gives a "hard copy" (Cosin, 1998).

\section{THE COMPUTER SOFTWARE}

A software can be referred to as a set of instructions loaded into the computer that tells it what to accomplish (and sometimes how to accomplish the task). Here, the term software is used in a generic sense and is categorized into system software (meaning operating system programs), application software (meaning programs that control the actual work), and utility software (meaning programs that perform certain other vital service functions). This is depicted in Fig. 2. What this means is that you will need to write a software containing a set of instructions that will boot your computer, another set of instructions on what tasks to accomplish and another set of instructions on what to do when one thing or the other goes wrong. 


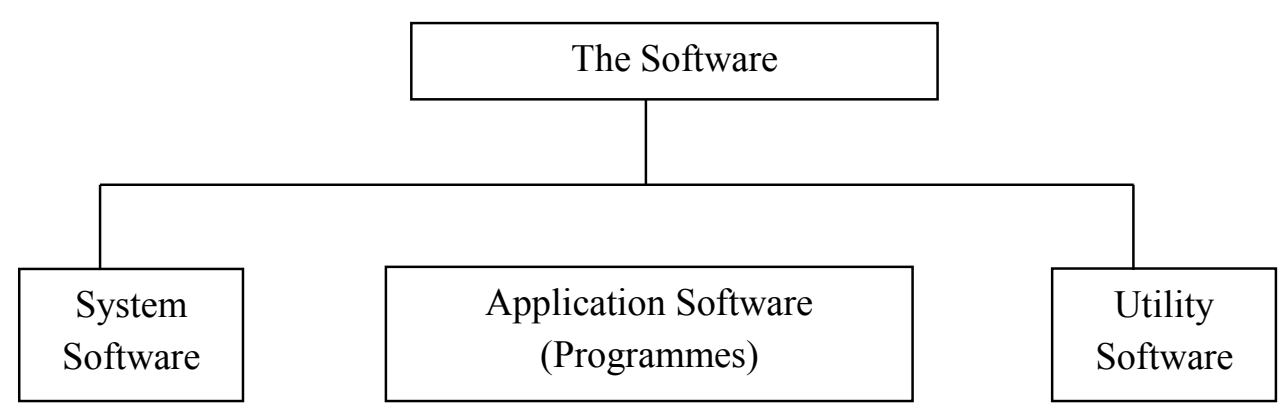

Fig. 2. The Computer Software.

The system software (or more commonly, the operating system) is essentially a code of instructions written for the computer in high level language such as BASIC, FORTRAN, PASCAL, COBOL, and so on which instructs the computer on how to behave (Eastman 1995). The computer can only take instruction when it is switched on. Once turned on, it looks for "directives" and the process of taking these directives is known as booting.

The second type of software a computer needs to function is the Application Software which is also a set of instructions and procedures geared toward specific kinds of tasks other than booting. There is an enormous variety of application software available to computer users and these can be grouped into categories as in Tablel below:

Table 1. Categories of Application Software.

\begin{tabular}{|c|c|}
\hline Category of software & Examples of Specific Software \\
\hline General & $\begin{array}{c}\text { Communication software, Personal Information Managers } \\
\text { The Encyclopedia }\end{array}$ \\
$\begin{array}{c}\text { Word processors (Desktop Publishing Packages) } \\
\text { spreadsheet, Database (ACCESS) Presentation } \\
\text { (Power Point) }\end{array}$ \\
\hline Professional & $\begin{array}{c}\text { Computer Aid Drawing(CAD) } \\
\text { Geographic Information System(GIS) }\end{array}$ \\
& SPSS (Statistical Package For Social Sciences)EPI \\
\hline
\end{tabular}

The General category of application software mainly includes programs that every computer user may at one time or the other have need for. These include communication software (for e-mail and access to the internet or any other network group) Personal Information Managers (for keeping schedules, and addresses), the Encyclopedia, other e-books and the office of suite sub-group. The professional category of the application software are those programs that only social scientists are more likely to require their use and these include such programs as Arc view, ArcInfo, and Idiris (for GIS), SPSS and EPI (for statistical analysis). 
The utility software is the third category of software and it is also a set of instructions and procedures geared toward specific kinds of tasks which the user can take advantage of. A typical example is the printer driver which comes with every printer one acquires. Its main function is to make available to the computer all the features of the printer and to ensure full compatibility between the two (Liman, 2004).

\section{CHALLENGES TO E-EDUCATION IN NIGERIA}

In Nigeria, experiences are accentuating unprepared net to fully exploit the merit of ICT in education owing to some infrastructural challenges; poverty and illiteracy. Prince (2009), stated that, a study conducted by the Global Information Technology (2005) used the Network Readiness Index (NRI), covering a total of 115 economies in 2005-2006, to measure the degree of preparation of a nation or community to participate in and benefit from ICT developments.

Nigeria was ranked $90^{\text {th }}$ out of the 115 countries surveyed. Likewise, Nigeria was ranked $86^{\text {th }}$ out of 104 countries surveyed in 2004 which shows a decline in Nigeria preparedness to participate in and benefit from ICT developments. Despite the fact that ICT holds great potentials in supporting and augmentation existing educational as well as national development efforts in Nigeria, several challenges remain (Mac-Ekemanjima, 2009).

These challenges include:

1. Inadequate ICT Infrastructure including computer hardware and software high, and bandwidth access.

2. Lack of skilled manpower to manage available systems and adequate training facilities for ICT education at all levels.

3. Resistance to change from traditional pedagogical methods, to move innovative, technology based and learning methods, by both students and academics.

4. The overall education is underfunded, therefore, available funds are used to solve urgent and important survival needs by the institutions.

5. The over-dependence of educational institutions on government for everything has limited institutions ability to collaborate with the private sector or seek alternative funding sources for ICT educational initiatives, and

6. In-effective co-ordination of all various ICT programs for education initiatives.

\section{CONCLUSION}

Information and Communication Technology (ICT) has a gigantic role to play in enhancing sustainable development in Nigeria although there exist so many factors that deteriorate its application in the county. The use of internet in Nigeria is so open that individual or cooperate has no binding rules as regard to their operation and even if exist, the laxity of the authority concerned make criminals manipulation inevitable. It is clear that the host of most ICT facilities and its operation exist only in urban setting due to slow developmental stage. Moreover, the ICT - based learning has the potential to guarantee a sustainable development through raising the standard and quality of Nigerian education but yet the country is said to be unprepared and thereby negated from taking advantage to achieve sustainable development. 


\section{Recommendations}

1. ICT infrastructures including computer hardware and software should be made available in all our educational institutions.

2. Skilled manpower as well as training facilities for ICT should be provided adequately at all levels.

3. People should be enlightened and oriented so as to be able to accept changes and innovations particularly the technology based and learning methods.

4. Education sector should be funded adequately to cater for all learning needs and aspirations.

5. The government of Nigeria in particular should get ready and prepare to participate in and benefit from ICT development.

6. There should be effective co-ordination of all ICT programs for education initiatives.

\section{References}

[1] Abolade A.O.,Olalere M. Y., (2005). Information and Communication Technologies (ICTs) Higher Teacher Education Program. African Journal at Educational Studies, 3(1); $1-19$.

[2] Anderson N., Baskin C. (2002). Can we leave it to chance? New Learning Technologies and the Problem of Professional Competence. International Education Journal, 3(3), 126-137.

[3] Bhatnagar S. C., Ramani R. V. (1999). Computers and Information Management. A primer for Practicing Managers $2^{\text {nd }}$ Edition Prentice Hall, India

[4] C-Tech Association (2010). 'Introduction to Network Cabling - Copper-Based System'. A study guide version 3,3,1 C-Tech Associates, Inc.

[5] Eastman R. J. (1995). Idrisi for Windows: User's Guide Version1, Idris, Production, Clark University, Worcester M.A

[6] Felix K. O. (2007). Information and Communication Technologies in Teacher Training and Professional Development in Nigeria. Turkish Online Journal of Distance Education, 8(1); Article II.

[7] Federal Republic of Nigeria (2001). Nigerian National Policy for Information Technology, Abuja NITDA.

[8] Jinghan M. L. (1997). Economics of Development and Planning Delhi; Vikas Press.

[9] Kischner P., Selinger M. (2003). The State of Affairs of Teacher Education with Respect to Information and Communication Technology. Technology, Pedagogy and Education, 12(1); 5-17.

[10] Liman M. M. (2004). The Use of Computers as Instructional Technology in Secondary Schools in Kano Metropolis. PGDE Project, Department of Education, Bayero University Kano.

[11] Mac-Ikemanjima D. (2005). "E-education in Nigeria: Challengers and Prospects". $8^{\text {th }}$ UN ICT Task Force Meeting. Dublin Ireland April 13-14. 
[12] Milken Exchange on Education Technology (1998). Technology in American Schools: Seven Dimensions for Gauging Progress. Retrieved February, http://www.mff.org/pubs/me/58.Pdf

[13] Moseley D., Higgins S. (1999). Ways forward with ICT. Effective Pedagogy using Information and Communication Technology for Literacy and Numeracy in Primary Schools. London, Teacher Agency.

[14] Osin L. (1998). Computers in Education for Developing Countries Why and How? Education and Technology Notes Series 3(1); 1-14.

[15] Prince N. O., Egba A. U., Elemchukwu D. E (2007). ICT and Distance Education Program in Sub-Saharan African Countries: A Theoretical Perspective, Journal of IT Impact, 7(3); 181.

[16] Tutu (2007). Survey on Digital Divide Among Sub-Saharan African Countries, Nigeria's Country Report. http://www.nitda.gov.ng/docs/policy/ngipolicy.pdf

[17] Williams K. (2003). Literacy and Computer Literacy: Analysing the NRC'S being fluent with Information Technology. The Journal of Literacy and Technology 3(1).

[18] World Commission on Environment and Development (1987). Our Common Future. WCED London Oxford University Press.

[19] Abdulrahaman W. Lawal, International Letters of Social and Humanistic Sciences 3 (2014) 53-59.

[20] Alaba E. Dare, International Letters of Social and Humanistic Sciences 3 (2014) 73-79.

[21] Grema Maina Bukar, Yohanna A. Timothy, International Letters of Social and Humanistic Sciences 4 (2014) 9-21.

[22] M. N. Modebelu, F. K. Igwebuike, International Letters of Social and Humanistic Sciences 4 (2014) 40-48.

[23] Akor Isaiah Akem, Victor Tavershima Ukeli, International Letters of Social and Humanistic Sciences 4 (2014) 49-59.

[24] Sule Maina, International Letters of Social and Humanistic Sciences 4 (2014) 87-96.

[25] Nwachukwu Uche Emma, International Letters of Social and Humanistic Sciences 5 (2014) 1-12.

[26] Peace Ebele Ilechukwu Chukwbikem, International Letters of Social and Humanistic Sciences 8(1) (2014) 1-17.

[27] Odo John Ogar, International Letters of Social and Humanistic Sciences 8(1) (2014) 28-33.

[28] Halima Sidi Bamall, International Letters of Social and Humanistic Sciences 8(1) (2014) 50-55.

[29] Elizabeth Morenikeji Titilayo Adediran, Albert Oluyomi Kehinde, International Letters of Social and Humanistic Sciences 8(1) (2014) 66-75.

[30] S. A. Kazeem, K. Y. Balogun, International Letters of Social and Humanistic Sciences 8(2) (2014) 108-119. 
[31] Nneka Rita Udoye, Victor Etim Ndum, International Letters of Social and Humanistic Sciences 8(2) (2014) 130-139.

[32] Sanusi L. Sa'adatu, International Letters of Social and Humanistic Sciences 8(2) (2014) 140-147.

[33] Dennis Agama Eka, International Letters of Social and Humanistic Sciences 8(2) (2014) 170-182.

[32] Nayereh Shahmohammadi, International Letters of Social and Humanistic Sciences 8(2) (2014) 183-191.

[33] Godwin E. Itua, International Letters of Social and Humanistic Sciences 8(3) (2014) 200-207.

[34] Rowland U. Aleshi, Clementina N. Iloh, International Letters of Social and Humanistic Sciences 8(3) (2014) 208-216.

[35] Hannatu Abdullahi, International Letters of Social and Humanistic Sciences 8(3) (2014) 217-223.

[36] Fowoyo Joseph Taiwo, International Letters of Social and Humanistic Sciences 8(3) (2014) 244-251. 